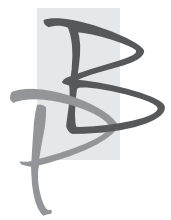

\title{
Michał Siedlecki*
}

Dział Naukowy Książnicy Podlaskiej im. Łukasza Górnickiego w Białymstoku https://orcid.org/0000-0002-7575-6799

\section{Zbieżność światów w twórczości Wiesława Myśliwskiego}

[rec. Piotr Biłos, Powieściowe światy Wiesława Myśliwskiego, Kraków, Wydawnictwo „Znak”, 2017, ISBN 978-83-240-4551-8, ss. 526.] $]^{1}$

Streszczenie: Michał Siedlecki w swojej recenzji monografii Piotra Biłosa zatytułowanej Powieściowe światy Wiesława Myśliwskiego dowodzi, że badacz ten opiera własną analizę utworów autora Nagiego sadu na idei, wedle której w dziełach prozaika główną funkcję znaczeniową odgrywa jedność światów przedstawieniowych jego powieści (ich fabularno-narracyjnych motywów oraz wątków). Mimo odważnych sądów uczonego, przewartościowujących obecne spojrzenie na dorobek literacki Myśliwskiego, jego książka stanowi istotną interpretację tekstów pisarza.

Słowa-klucze: Wiesław Myśliwski, Piotr Biłos, współczesna proza polska, monografia, interpretacja.

* Michał Siedlecki - dr, pracownik Działu Naukowego Książnicy Podlaskiej im. Łukasza Górnickiego w Białymstoku oraz stały współpracownik Katedry Badań Filologicznych „Wschód - Zachód" w Kolegium Literaturoznawstwa Uniwersytetu w Białymstoku. Autor monografii Myśliwski metafizyczny. Rozważania o ,Widnokręgu” $i$,,Traktacie o luskaniu fasoli” (Białystok 2015) oraz licznych artykułów naukowych z pogranicza literatury XX wieku i współczesnej.

1 Prezentowana tu książka Piotra Biłosa o Wiesławie Myśliwskim została równolegle wydana w języku francuskim. 


\section{The convergence of worlds in the works of Wiesław Myśliwski} [rev. Piotr Biłos, Powieściowe światy Wiesława Myśliwskiego (Worlds in the novels of Wiesław Myśliwski), Cracow, "Znak" publishing house, 2017, ISBN 978-83-240-4551-8 pp. 526]

Summary: Michał Siedlecki, in his new review of the monograph by Piotr Biłos entitled Powieściowe światy Wiesława Myśliwskiego (Worlds in the novels of Wiesław Myśliwski), shows that in the study of the works written by the author of Nagi Sad (Bare Orchard) the researcher has based his own analysis on the idea that the main function of meaning in this writer's works is performed by the unity of worlds presented in his stories (their feature and narrative motifs, as well as plots). Despite researcher's bold opinions, re-examining current approach to the Myśliwski's literary oeuvre, his study is a significant interpretation of the author's texts.

Key words: Wiesław Myśliwski, Piotr Biłos, modern polish prose, monograph, interpretation.

Omawiana tu książka Piotra Biłosa wydaje się ważnym tekstem na mapie prac literaturoznawczych badających twórczość Wiesława Myśliwskiego. Liczy ponad pięćset stron. Składa się z trzech części podzielonych na kilkadziesiąt rozdziałów i podrozdziałów w każdej z nich. Poprzedza je analityczny wstęp badacza, a wieńczy zakończenie, bibliografia, indeks postaci oraz nazwisk, jak też źródła ilustracji. Została opublikowana w 2017 roku przez Wydawnictwo ,Znak” przy wsparciu francuskiego instytutu Centre de recherches Europes-Eurasie (Inalco, Paris). Przyjrzyjmy się jej teraz szczegółowo, mając na uwadze inne tego typu dysertacje powstające na temat dorobku prozatorskiego autora Ostatniego rozdania (2013).

\section{Jedno dzieło}

Warto na wstępie naszych rozważań zaznaczyć, że dotychczas ukazały się następujące monografie dotyczące twórczości Wiesława Myśliwskiego: a) Jerzy Ablewicz, Wiesław Myśliwski, Kielce 1988; b) Czesław Dziekanow- 
ski: Proza „życia w śmierci”. Psychoanaliza twórczości powieściowej Wiesława Myśliwskiego, Białystok 1990; W Imię Ojca i Syna, Warszawa 1993; Życie jaśnie pana, Warszawa 1994; Życie w śmierci, Warszawa 1995; c) Bogumiła Kaniewska: Wiesław Myśliwski, Poznań 1995; Opowiedziane. O prozie Wiesława Myśliwskiego, Poznań 2013; d) Jan Pacławski, A jeśli chodzi o moje pisanie... O pisarstwie Wiestawa Myśliwskiego, Kielce 2011; e) Ewa Pindór, Proza Wiesława Myśliwskiego, Katowice 1989; f) Michał Siedlecki, Myśliwski metafizyczny. Rozważania o ,, Widnokręgu” $i$, Traktacie o tuskaniu fasoli”, Białystok 2015 oraz g) Karolina Wawer, Drugi plan. Twórczość Wiestawa Myśliwskiego w perspektywie postkolonialnej, Kraków 2018. O ile do ostatniej pozycji nie miał się prawa badacz odnieść, gdyż została ona wydana rok po jego publikacji, to zadziwia fakt, że w swojej książce bazuje wyłącznie uczony na trzech pierwszych wymienionych tu autorach. Interpretator skupia się tutaj głównie na psychoanalitycznej tradycji badawczej spod znaku tekstów Dziekanowskiego. Ponadto, powołuje się często między innymi na opracowania Rocha Sulimy, Zygmunta Ziątka, Henryka Berezy czy Jana Błońskiego, acz robi to dość wybiórczo. Całość dopełnia u niego hermeneutyczna analiza dzieł pisarza.

Główną ideą książki Piotra Biłosa pozostaje jedność światów przedstawieniowych w powieściach Wiesława Myśliwskiego (ich fabularno-narracyjnych motywów i wątków). Wszystkie utwory polskiego pisarza to - wedle śmiałej, choć ostatnio dosyć modnej, tezy badacza - jedno wielkie dzieło literackie, co podkreśla on już na wstępie dociekań, broniąc zarazem ich zasadności w dalszych partiach rozważań. Koncepcja jego zda się dość frapująca, wsparta $\mathrm{w}$ wielu miejscach psychoanalityczną metodologią (głównie pracami Czesława Dziekanowskiego), acz nie wyzbyta niekiedy niebezpiecznych uproszczeń, mogących dezawuować sens i przesłanie prozatorskich tekstów autora Nagiego sadu (1967). Biłos twierdzi bowiem jednoznacznie na pierwszych stronicach swej monografii, że: „Między powieściami [Myśliwskiego - M. S.] ujawniają się strukturalne analogie, echa, symetrie bądź opozycje, wznowienia, powtórzenia oraz wariacje, związane zarówno ze snutymi wątkami, jak i obraną formą narracyjną"2.

2 P. Biłos, Powieściowe światy Wiestawa Myśliwskiego, Kraków, 2017, s. 12. Por. Cz. Dziekanowski, Proza ,życia w śmierci”. Psychoanaliza twórczości powieściowej Wiesława Myśliwskiego, Białystok 1990; tegoż, Wimię ojca i syna, Warszawa 1993; tegoż, Życie jaśnie pana, Warszawa 1994; tegoż, Życie w śmierci, Warszawa 1995; tegoż, Narodziny ojca (Psychoanalityczna inter- 
To jednak, że coś wydaje się ze sobą zbieżne, nie uprawnia nas do uogólniania, formułowania ad hoc koncepcji o jakimś tajnym planie Myśliwskiego, by swe utwory zamknąć w jedną całość, oddzielając je tylko od siebie odrębnymi tytułami i z pozoru odmienną scenerią. Spłyca to jedynie dorobek prozatorski pisarza. Myśliwski nie tworzy żadnej sagi, choć pewne elementy wspólne da się u niego niewątpliwie odnaleźć. Uniwersa utworów autora $\mathrm{Pa}$ Łacu (1970) stanowią swego rodzaju autonomiczne byty. Nie warto ich na siłę ze sobą scalać. O ile pojęcie „literatury chłopskiej” (zob. Henryk Bereza) nie wystarcza, by dobrze zinterpretować wszystkie dzieła pisarza, to badanie ich przez pryzmat prozy dokumentu osobistego (vide Zygmunt Ziątek) czy metafizyki może wydawać się zasadniejsze niż zwodnicze niekiedy meandry psychoanalizy, której badawcze podwaliny zostały między innymi zdeprecjonowane przez Carla Gustava Junga (1875-1961)3. Tymczasem Biłos tak oto formułuje swoje twierdzenia:

Tych ech, śmiało wykraczających poza granice poszczególnych powieści, jest bardzo dużo. Nawet jeśli trudno je wyczuć przy pierwszej lekturze - da się je dostrzec przy dłuższym obcowaniu z działami autora, przez powroty do nich, cykliczne i zarazem uparte, by tak rzec, odśrodkowe. Czytelnik musi oswoić się z faktem, że niezależnie od wątku, na którym w danej chwili skupia się narracja, istnieje duże prawdopodobieństwo, że wchodzi on w rezonans $z$ analogicznymi wątkami w pozostałych powieściach4.

pretacja „Nagiego sadu”), „Twórczość” 1990, nr 5, s. 29-51; tegoż, Estetyka niedostatku, „Miesięcznik Literacki” 1984, nr 10, s. 60-71 oraz tegoż, Psychoanalityczna interpretacja ,Kamienia na kamieniu” Wiesława Myśliwskiego. Bohater i narrator w „Kamieniu na kamieniu”, „Przegląd Humanistyczny" 1990, nr 12, s. 51-63. Zob. H. Bereza, Zwiazki naturalne. Szkice literackie, Warszawa 1972; tegoż, Czytane w maszynopisie, Spetnienie, „Twórczość” 1983, nr 2, s. 162-164; tegoż, Przynależność do świata, „Tygodnik Kulturalny” 1968, nr 25, s. 4; tegoż, Nowy homo novus, „Twórczość” 1971, nr 4, s. 100-102; tegoż, Czytane w maszynopisie, Przypis, „Twórczość” 1984, nr 2, s. 156-157; tegoż, Potwierdzenie, „Polityka” 1985, nr 51/52, s. 7; tegoż, Osiagalność, „,Twórczość” 1996, nr 11, s. 48-52 oraz tegoż, Petnia, „Twórczość” 2007, nr 3, s. 93-96.

3 Zob. Z. Ziątek, Wiek dokumentu. Inspiracje dokumentarne w polskiej prozie wspótczesnej, Warszawa 1999; tegoż, Głód syntezy. Wiesław Myśliwski i proza chtopska, [w:] Sporne postaci polskiej literatury współczesnej. Następne pokolenie, red. A. Brodzka i L. Burska, Warszawa 1995, s. 151-168; tegoż, Ojciec i syn, „Miesięcznik Literacki” 1968, nr 7, s. 119-121; tegoż, Nowy widnokrag (Z okazji czwartej powieści Wiesława Myśliwskiego), „Teksty Drugie” 1997 nr 5, s. 153-168 oraz tegoż, Wiesław Myśliwski: 75 lat życia, 40 twórczości, „Odra” 2007 nr 12, s. 63-65. Zob też M. Siedlecki, Myśliwski metafizyczny. Rozważania o ,Widnokręgu” i ,, Traktacie o tuskaniu fasoli”, Białystok 2015.

\footnotetext{
$4 \quad$ P. Biłos, dz. cyt., s. 14.
} 
Aż chciałoby się wejść w jawną polemikę z Biłosem, że skoro przy pierwszej lekturze książek Myśliwskiego nie da się obronić zasugerowanej powyżej tezy badacza, to dlaczego trzeba je czytać po raz wtóry, by na siłę udowadniać jej zasadność. Utwory pisarza są przecież samowystarczalne. Mogą korespondować ze sobą w warstwie językowej, wszak każdy pisarz posługuje się własnym lingwistycznym kodem. Jednak nie da się zrobić z nich jednego królestwa zdarzeń i postaci. Biłos posługuje się nawet w analizie tekstów jednym z tytułów jego powieści, a mianowicie terminem „widnokrąg”, który stanowi metaforyczną klamrę rozważań uczonego. Ma on - według niego - nieskończony rezerwuar zastosowań. Jest horyzontem, będącym źródłem odwiecznych sprzeczności, który wyłania się jednak zza fabularnych historii Myśliwskiego. Wydaje się ich tajemną nicią przewodnią. Jego dwuznaczność, podszyta nierozstrzygalnością, określa go - zdaniem badacza - najlepiej ${ }^{5}$. Czy Biłos nie stosuje tu przypadkiem pewnej nadinterpretacji? Oddajmy raz jeszcze głos autorowi recenzowanej dysertacji.

Widnokrąg wciela w życie - podług słów Biłosa - zasadę ciągłego odraczania, odsuwania dalej. W filozofii Derridiańskiej nosi to nazwę „różni” (z franc. différance). Wszystko zda się u Myśliwskiego igrać z niemożnością wypełnienia się jednoznacznego końca lub początku. Powraca zarazem do nierozstrzygalności, a więc względności wszelkich opozycji i sytuuje w centrum uwagi figury oczekiwania, jak też obecności. Co rusz są one zresztą odraczane czy drążone wewnętrznie przez wszelakie różnice ${ }^{6}$. Dzieje się tak dlatego, gdyż: ,[...] historia mająca nastąpić nigdy nie wymazuje tej, która właśnie jak nam naiwnie się zdawało - dobiegła końca [...]"7. Lecz dzieje się tu wręcz przeciwnie. Zostaje ona dopełniona i wewnątrz tak wykrystalizowanego kręgu należy ją odczytać po raz wtóry jako ślad zapowiadający tak zwane wariacje wprowadzane przez każdą kolejną powieść ${ }^{8}$.

Czy aby jednak na pewno słowo „widnokrąg” jest najlepszym kluczem interpretacyjnym prozy Myśliwskiego? Czy nie bardziej zasadny okazałby się do egzegezy jego utworów termin „traktat” bądź „epopeja”? Wszak

5 Tamże, s. 16.

6 Tamże, s. 17-18.

7 Tamże, s. 19.

8 Tamże. 
o Kamieniu na kamieniu (1984) pisano swego czasu jak o spełnionej epopei chłopskiej (zob. Dariusz Kulesza), zaś jeden z utworów pisarza nosi tytuł Traktat o tuskaniu fasoli (2006), przy czym wyraz „traktat” można by chyba zastosować do wszystkich tekstów prozaika z racji ich nader filozoficznego tonu'. I na tym gruncie warto szukać wszelkich wewnątrztekstowych paralelizmów u Myśliwskiego. Biłos wydaje się jednak w swoich odważnych sądach na wskroś konsekwentny i „ideologicznie niereformowalny”. Oto co pisze on parę stron dalej:

U Myśliwskiego powieści wchodzą ze sobą w rezonans, i to ta wibracja powoduje, że stabilizacja formy tworzy zjawisko tylko powierzchowne, obowiązujące dopóty, dopóki czytelnik upiera się przy sztucznym odgradzaniu tych powieści od siebie. [...] Dzieje się tak, jakby wrażliwość pisarza, przechodząc od jednej powieści do następnej, wywierała nacisk na formy, w które powieści się oblekają, przy czym wytwarza dynamikę, wskutek której wykwit tego, co nowe, i nawrót pewnych trwałych punktów splatają się nierozerwalnie ze sobą ${ }^{10}$.

Czytelnik, który się upiera i stroni od rozumienia dzieł Myśliwskiego, podług zapatrywań Biłosa, wydaje się de facto „gorszy” z tego powodu, że traktuje je wszystkie jako osobne struktury prozatorskie. To przecież zakrawa na paradoks. Trudno się z tymi argumentami w pełni zgodzić. Tym bardziej, że po Kamieniu na kamieniu uniwersum wiejskie powieści Myśliwskiego podlega radykalnej transformacji, otwierając się na świat zarezerwowany dla przestrzeni miejskich. W uchu igielnym (2018) wieś praktycznie w ogóle nie istnieje, a w Traktacie o tuskaniu fasoli pojawia się nawet Wiedeń. Trudno chyba zatem czytać te utwory jako jedną całość.

9 Zob. D. Kulesza, Chrześcijański mit słowa i ciała. Święty Jan, Tolkien, Myśliwski, [w:] Mity stowa. Mity ciała, red. L. Wiśniewska, M. Gołuński, A. Stempka, Bydgoszcz 2007, s. 5160; tegoż, Sacrum wiejskiego uniwersum. „Kamień na kamieniu” Wiesława Myśliwskiego, [w:] Literatura i wiara, red. A. Sulikowski, Szczecin 2009, s. 339-352; tegoż, Więcej niż cykl. Kilka uwag o twórczości Wiestawa Myśliwskiego, [w:] Cykle i cykliczność. Prace dedykowane Pani Profesor Krystynie Jakowskiej, red. A. Kieżuń, D. Kulesza, Białystok 2010, s. 93-106 oraz tegoż, Notes albo widok ze szczytu. O twórczości Wiestawa Myśliwskiego nie tylko w zwiazku z ,Ostatnim rozdaniem”, „Próby” 2004, nr 2, s. 14-33. Zob. też tegoż, Epopeja. Myśliwski, Herbert, Mrożek, Białystok 2016.

10 P. Biłos, dz. cyt., s. 21-22. 


\section{Sens globalny}

Biłos wierzy w sens globalny utworów Myśliwskiego. Zdaje się on przez pisarza nieustannie obmyślany. Teksty artysty pozostają bowiem - zdaniem badacza - uwikłane w tkankę narastających bez końca lokalnych analogii, jak też różnic. Wszystko wydaje się tu podszyte grą zachodzącą między materią dzieła, jego widocznymi na wierzchu formami a ukrytą wrażliwością samego twórcy. Autor Widnokręgu (1996) opowiada się - w opinii uczonego - po stronie ,ja" egzystencjalnego, osobnego, częściowo mglistego i niejasnego, także $\mathrm{w}$ przypadku siebie samego ${ }^{11}$. $\mathrm{O}$ ile $\mathrm{z}$ powyższymi tezami można by w pewnym sensie polemizować na gruncie literacko-filozoficznym, to Biłos słusznie zwraca uwagę $\mathrm{w}$ dalszej części swych dociekliwych rozważań na wypowiedź Myśliwskiego o uniwersalnej i stricte literackiej wymowie jego twórczości:

Ja zawsze widziałem kulturę chłopską w jej uniwersalnym wymiarze - bliskie jest mi to, co w niej ogólnoludzkie, a nie folklor, obyczajowość, zewnętrzność. U nas tymczasem stawiano znak równości między chłopskim nurtem literatury a powieściami o wsi" ${ }^{12}$.

Wszystkie przecież utwory Myśliwskiego mają wymiar uniwersalny, co wcale nie oznacza, że wspomniana uniwersalność w każdym z dzieł prozaika posiada tożsame oblicze. Różnią się one wszak od siebie, na przekór sądom Biłosa, pewnymi odcieniami znaczeniowymi i sensem fabularnym. Są niczym równoległe wszechświaty, acz o odmiennej trajektorii zdarzeń i historii opisywanych weń postaci. Trudno je rozpatrywać przez pryzmat powieściowej jedni. Za dużo jest między nimi wszelakich dyferencjacji. Owszem, nie sposób nie zgodzić się z autorem książki Exil et modernité. Vers une littérature à l'échelle du monde: Gombrowicz, Herling, Milosz (2012), który twierdzi, iż Myśliwski daje swojemu czytelnikowi wyraźnie do zrozumienia, że jednym z naczelnych obiektów jego zainteresowania pozostaje zagadnienie „ja”, a więc ,[...] kwestia indywidualności człowieka, wyjątkowej i będącej

11 Tamże, s. 22.

12 Cyt. za P. Biłos, [w:], tamże: K. Masłoń, Miłość nie jest nam dana, Warszawa 2005, s. 25. 
w ciągłej przebudowie"13. Nie da się jednakże analizować poczynań i cech charakterologicznych głównych bohaterów jego książek jako bliźniaczych w nich indywiduów, skrytych jedynie pod odmiennymi imionami czy rangą społeczną, którą aktualnie piastują. Zbyt wiele bowiem ich dzieli niż łączy. To paradoksy, którym trudno się raczej przeciwstawić. Biłos zdaje się wręcz potwierdzać powyższy sąd, sam sobie w pewnym sensie przecząc, czy tworząc poniekąd wzajemnie negujące się tezy:

Uniwersalność powieści Myśliwskiego nie opiera się wyłącznie na tym, co wspólne wszystkim ludziom, ale także na tym wszystkim, co walnie przyczynia się do odróżniania się ludzi od siebie. Jej dynamika zakłada powstawanie jednostek do niczego niepodobnych, zawsze różnych i wyjątkowych ponad wszelkimi przynależnościami - płciowymi, społecznymi, historycznymi, politycznymi, pokoleniowymi itp. ${ }^{14}$

Dziwna to wszak uniwersalność, gdzie wszystko się od siebie różni. Tym bardziej, gdy mowa o utworach Myśliwskiego, które, wedle Biłosa, toczą ze sobą subtelny dyskurs. Monografia badacza ujawnia zresztą dużo takich sprzecznych sądów. Uczony twierdzi nawet w pewnym momencie, że wszystkie powieści prozaika są przesycone intertekstualnymi echami. To - wedle jego słów - jedna z ich najbardziej rozpoznawalnych cech. Powyższe sprawia więc, że chłopska kondycja rozlokowana tu została w szerszym kontekście, w którym przedstawia się jako materiał oraz podłoże, na którego kanwie pisarz wysnuwa filozoficzno-estetyczne rozmyślania noszące dość ,„[... głębokie piętno indywidualnej świadomości, doskonale zdającej sobie sprawę ze swojej osobliwości i wyjątkowości (uniqueness), a zatem cech, dzięki którym zyskuje wymiar uniwersalny"15.

Czy jednak osobliwość i wyjątkowość nie świadczą raczej o autonomiczności każdego z utworów pisarza? Czy nie traktują one o osobnych światach, pełnych wielu różnorodności? Czy wymienione przez Biłosa cechy można przypisać wszystkim tekstom Myśliwskiego? To pytania natury retorycznej.

13 P. Biłos, dz. cyt., s. 25.

14 Tamże, s. 26-27.

15 Tamże, s. 60-61. 
Sądy badacza oscylują bowiem często między wieloma skrajnymi poglądami. Nie dziwią nas więc wątpliwości, z którymi musimy się tutaj borykać. Z jednej wszak strony twierdzi uczony o wszechobecności, jaką zyskuje ,ja” w utworach prozaika, z drugiej uważa, że nie opiera się ona na wykluczeniu inności oraz zewnętrzności, acz na ich ciągłym i twórczym przywoływaniu. Narracyjny stelaż (dyspozytyw) staje się tu okazją do przedstawienia, jak głęboki pozostaje stopień zaangażowania ,ja”-opowiadacza w niniejszą „,[...] grę sił, raz na zawsze przekreślającej wszelkie rojenia o tym, że można by się stać samowystarczalnym i wszechwładnie panować nad pozostałymi bytami”'16. Jest więc narrator u Myśliwskiego wszechobecny i wszechwładny czy też nie? Jaki on jest w rzeczywistości? Dlaczego tak się dzieje?

Biłos nie udziela nam jednoznacznej odpowiedzi na te pytania, a raczej skrzętnie lawiruje między nimi, kreśląc swoją wizję uniwersum powieści Myśliwskiego. Dodaje tylko kilka uwag o mimesis tekstów artysty, która ciągle się waha między ,ja" opowieści ramowej a zdarzeniami, pozostającymi przedmiotem owej opowieści. Samo zatem ,ja” opowiadacza, pytania, które powstają w związku z jego stanem ducha czy sytuacją bieżącą, mogą wzbudzać potencjalne zainteresowanie czytelnika, płynnie przechodzące od konkretnej fabuły do sytuacji jej tak zwanego sprawcy. Punkt ciężkości powieści Myśliwskiego nie tylko skłania się - zdaniem Biłosa - ku fabule, w której przyszyły opowiadacz odgrywa sukcesywnie ,[...] jedną z głównych ról, lecz także ku owemu «ja» narracyjnemu - którego obecność odczuwamy w sposób wręcz fizyczny. Niemniej w to nasze obcowanie z nim zawsze wkrada się element pewnej nieprzeniknioności”'17. Z zaprezentowanych tu uwag badacza nie sposób jednak w żaden sposób wywnioskować tezy o jedności dzieł Myśliwskiego, a jedyne, co możemy w tym miejscu zauważyć, to pewien rodzaj tożsamej w nich struktury narracyjnej, która wynika w głównej mierze ze swoistego stylu pisarskiego omawianego tu twórcy. Wzmiankuje on tutaj zresztą dosyć często o roli ,ja" w książkach autora Nagiego sadu:

Każda powieść Myśliwskiego kreuje tę obecność „ja”, wokół którego, niejako na naszych oczach, ona powstaje. Rychło rozumiemy, że owo „ja” wrośnięte jest

16 Tamże, s. 74.

17 Tamże, s. 87. 
w opowieść, i że ów splot „ja” - opowieść to swoisty punkt podparcia ruszający z posad bryłę przeszłości, świat odziedziczony, który „ja” przejmuje, aby nadać mu nową wartość przez snucie o nim opowieści ${ }^{18}$.

W podobnym tonie wypowiada się tu Biłos wielokrotnie: „Odkąd się pojawiło, «ja» [w tekstach Myśliwskiego - M. S.] przestało być nam obojętne. Rychło odczuwamy je jako obdarzone bogatą osobowością, a nawet bujnym temperamentem, wielką zdolnością do współczucia bliskim [...]"19 itd. Następnie dodaje, że przechodzenie u autora Pałacu od fikcji do rzeczywistości posiada u niego wymiar nader skomplikowany. Interesuje go ponadto żywotność jego powieści, która polega - zdaniem uczonego - na wciąż ponawianym wysiłku pisarza sprowadzającym się do odsłonięcia, a równocześnie pogłębienia przez artystę tego, jak fikcja potrafi mówić u niego prawdę o kondycji ludzkiej oraz o człowieku. Utwory Myśliwskiego roją się przecież - według Biłosa - od pytań dotyczących tego, jak sama rzeczywistość czy sytuacja bohaterów, z chwilą gdy zapładnia je tak zwana „fikcja”, sen oraz wyobraźnia, rozwarstwiają się na wielość ucieleśnień kreujących coraz to odmienne konfiguracje, wchodzących ze sobą w relacje ponad czasem. A w cyklu powieściowym, który Myśliwski tworzy przez dziesięciolecia, dąży on konsekwentnie ,[...] do pomnażania wariantów ontologicznych, co chwila roztwierających się przed każdą ludzką egzystencją"20.

Czy na pewno? Czy zasadne jest w takim razie mówienie o cyklu powieściowym autora Kamienia na kamieniu, skoro w każdej książce pisarza dominuje nieco inny model/wariant/kod ontologiczny? Dlaczego łączy je Biłos nieustannie w jedną całość? Pytania niniejsze zdają się też retoryczne. Uczony nie przedstawia bowiem dowodu na prawdziwość własnych tez. To są tylko zwyczajne domysły badacza, niepoparte raczej racjonalnymi przesłankami, z których można by wysnuwać odpowiednie wnioski. Jego uwagi są częstokroć ogólne. Brakuje im spójności. Nie dotyczą meritum przedkładanej pracy. Meandrują od wątku do wątku:

20 Tamże, s. 93. 
Jeżeli Myśliwski po mistrzowsku posługuje się formą powieściową, to właśnie dlatego, że pragnie pokazać jak najszerszy wachlarz możliwości, jaki wynika ze stanu zagubienia człowieka w świecie. Wysiłki egzystencjalne jego bohaterów to w dużej mierze próby odnalezienia swojego miejsca. Ale w tej kwestii nie ma prostych recept. Najczęściej każde rozwiązanie przeistacza się w - li tylko potencjalny - wariant. Słowem - nawet pozornie jednoznaczne odpowiedzenie na pytanie „Gdzie jest moje miejsce?" [...] prowadzi nieuchronnie do otwarcia się kolejnej, nowej furtki ${ }^{21}$.

Twierdzenia Biłosa dotyczą wielu aspektów twórczości Myśliwskiego, acz zdają się poruszać ich jednocześnie tak wiele, że gubią się wzajem w natłoku przytaczanych przez niego uwag i spostrzeżeń. Tymczasem zapoznajemy się z kolejnymi sądami badacza. Jego zdaniem, każdy składnik powieści Myśliwskiego, a w szczególności Pałacu, winien wywołać wrażenie bezpośredniości. Czytelnik ma tu bowiem cały czas poczucie, że coś rzeczywiście odbywa się jakby przed jego oczami. Potęguje je brak jakiegokolwiek procederu literackiego, który by nam ułatwiał przeniesienie się ze świata pozatekstowego do uniwersum książki, po którą sięgnęliśmy, i w której karty się bacznie zagłębiamy. Choć zwierzenia ,ja”-opowiadacza są tutaj dość autentyczne, dobrze wiemy, że stanowią one tylko fikcję. Opowieść została tu skierowany do jakiegoś „,ty”, nawet jeśli do tej pory ono się nam nie zaprezentowało. To, że pozostało ukryte, wcale nie oznacza, że tak będzie wiecznie ${ }^{22}$. Pałac bowiem, tak jak pozostałe powieści artysty, „[...] zakrywa swoją sztuczność przez wywołanie wrażenia zbieżności z fabułą oraz wszechmocy, jakiej dorobiło się «ja»"23. Podobnych spostrzeżeń Biłosa możemy znaleźć wiele o niemal każdym wydanym do tej pory utworze Myśliwskiego. Mają one charakter analityczny, acz z ich całości trudno stworzyć klarowny konstrukt potwierdzający główny sąd badacza. Bardziej niż o jedności, mówią one paradoksalnie o wielości światów Myśliwskiego.

23 Tamże, s. 129. 


\section{Wielopoziomowe dywagacje}

Biłos snuje w monografii wielopoziomowe interpretacje na temat tekstów Myśliwskiego. Uważa on na przykład, że w powieściach prozaika przeważają napięcie sił, nieustanne zróżnicowanie poziomów oraz, w głównej mierze, nadrzędność indywidualnego narratora. Odnoszą one zwycięski bój z samowystarczalnością, jak też z pełnią ukazywanego świata. Postać, a może poniekąd „,[...] figura «ja»-opowiadacza, bohatera, to istotnie wielkie wyzwanie dla czytelnika tych powieści - bo to wokół niego się one rozwijają, choć jednocześnie tego «ja» nie wysuwają na pierwsze miejsce”24. „Ja” okazuje się tu nierozłącznie związane z określonym „ty”, które poniekąd postuluje, a sytuacja komunikacyjna leżąca u podstaw utworów prozatorskich pisarza to jawne współdziałanie za pomocą słowa, które zwraca się ku sferom fantazmatów czy wyobraźni ${ }^{25}$. Taka wydaje się specyfika utworów prozaika. Trudno się z owymi sądami nie zgodzić, acz mają one raczej ogólną naturę. Nie wnoszą niczego nowego do bogatego dyskursu na temat twórczości autora Traktatu o tuskaniu fasoli.

Ważny dla Myśliwskiego wydaje się również - w opinii Biłosa - mechanizm tak zwanego odzyskiwania przeszłości, który wydaje się u prozaika nigdy nieukończony. Przypomina on proces wywoływania zdjęcia czy nawet umiejscawiania elementów świata oraz samego siebie w taki sposób, by przy optymalnych warunkach mogły wyjść na światło dzienne niektóre pogrążone w cieniu fragmenty dookolnej rzeczywistości. Ale równie istotna wydaje się „[...] sama zdolność przyglądania się tym zdjęciom po latach, umiejętność splatania aktualnego patrzenia z opowieścią ex post. To one tworzą prawdziwe światło rozświetlające białe plamy przeszłości"26. W nielinearnych utworach Myśliwskiego pojęcie czasu wydaje się zresztą dosyć względne. Wiele zdarzeń rozgrywa się tu bowiem równolegle. Trudno je temporalnie sprecyzować. Tworzą misterne dzieło, w którym olbrzymią rolę odgrywa świat archetypów oraz symboli. Biłos twierdzi również między innymi, że:

Powieści Wiesława Myśliwskiego opowiadają [...] w ten czy inny sposób o tym, jak syn powołany zostaje do tego, aby stać się ojcem. To on będzie grał rolę,

24 Tamże, s. 111.

25 Tamże, s. 136.

26 Tamże, s. 148. 
której ojciec nie był w stanie udźwignąć. Ale można także na to spojrzeć z innej strony. Synowi udaję się tak skutecznie przejąć władzę ojcowską, bo umiał on wykorzystać naukę, jaką ojciec go obdarzył. Swój sukces zawdzięcza zatem nie tylko upadkowi ojca, lecz także nauce, jaką odebrał od ojca ${ }^{27}$.

Relacja ojciec - syn wydaje się nader istotna w powieściach Myśliwskiego. Badacz opisuje ją dobrze, mając na uwadze wszystkie kluczowe aspekty poruszanego tematu. Syn-opowiadacz pozostaje - wedle jego opinii - jednostką, w której skupiają się wszelakie więzi międzypokoleniowe, znajdując ujście w materii danej opowieści. Ale status narratora umożliwia mu też w pewnej mierze uniezależnienie się od owych relacji. Dzieje się tak, gdyż opowieść wykorzystuje kreację oraz fikcję w celu nabrania swoistego dystansu do wątków biograficznych. Nawet jeżeli opowiadacz nieustannie jest synem, transcenduje on biologiczne ograniczenia nie tylko ludzkiej, ale wręcz ziemskiej kondycji. Bohater nigdy nie występuje tutaj sam. Zawsze łączy go więź z jakąś rodziną - jeżeli nie z biologiczną, to z zastępczą. Lokuje się tu w sytuacji głębokiej izolacji. Spory dystans dzieli go jednak od opisanych przezeń osób oraz zdarzeń. Oprócz wymiaru czasowego posiada on także walor ochronny. Opowieść przerabia bowiem u Myśliwskiego ,[...] materię przeszłości, nadając jej nowy kształt. Stanowi ona dla «ja» próbę stworzenia większej niż za życia bliskości ze wszystkim, o czym jego opowieść traktuje"28.

To oryginalne stwierdzenia Biłosa, w treści których to, co minione tworzy asumpt dla ,ja”-opowiadacza do intymizacji świata zewnętrznego, do symbolicznej kreacji jego kolejnych bytów. Ich nieustanne migotanie leży - według uczonego - u podstaw uniwersów opowiedzianych przez Wiesława Myśliwskiego. Wyznacza horyzont wszelakich prób ich analitycznego odczytania ${ }^{29}$. Z tych na pozór niewinnych sądów badacza może jednakże wynikać, że fabuły poszczególnych utworów prozaika pozostają na tyle płynne, by traktować poszczególne ich elementy jako wzajem koherentne oraz stale się przenikające. Zasadność takich rozmyślań wydaje się niczym nie podparta. To tylko jedna

Tamże, s. 168.

Tamże, s. 171. 
z możliwych teorii, w której wiarygodność przyszło nam tu od początku powątpiewać. Trudno też zgodzić się z tezą Biłosa, że stosunki międzyludzkie w powieściach autora Pałacu są przykładem związków intertekstowych w jego działach ${ }^{30}$. W ten sposób można by doszukiwać się wszelkich podobieństw interpersonalnych (vide główni bohaterowie współczesnych utworów literackich) u nawet obcych sobie gatunkowo pisarzy.

Biłos pisze też, że utwory Myśliwskiego mając z natury rzeczy naturę fikcjonalną, nie wykluczają zarazem stale powracających w nich motywów autobiograficznych. Te wszak pozostają zniekształcane oraz przetwarzane zgodnie z zasadami wyobraźni autorskiej. Powieści Myśliwskiego wyrastają przecież wedle badacza - z przekonania, że życie zawsze pozostaje opowieścią ${ }^{31}$. Dlatego też to właśnie fikcji Myśliwski stara się nadać jak najsilniej wymiar autentyzmu czy prawdziwości, większy wręcz niźli ten będący udziałem tak zwanej biografii i rzeczywistości, ba, nawet tak zwanej prawdy: biograficznej, politycznej, historycznej, społecznej itp. Uczony zadaje tu nader istotne pytanie:

Czy zresztą nie jest tak, że tamte prawdy i fakty - o czym mamy zwyczaj zapominać - także zrodziły się kiedyś z kreacji, inwencji, wyobraźni, a zatem opowieści? Jedynie opowieść jest w stanie przezwyciężyć opozycję faktów i zmyślenia, i przywrócić sens zarówno faktom jak i słowom ${ }^{32}$.

Utwory pisarza stanowią - w opinii Biłosa - zjawiskową próbę przywrócenia szlachetności nie tylko sztuce literackiej, ale w głównej mierze powieściowej. Impet nadaje im sam wysiłek kreacji struktury symbolicznej, dysponującej siłą zdolną do tego, by zatryumfować nad opozycją usytuowaną między prawdą a zmyśleniem i swą przewagę zapewnić takiemu zmyśleniu, o którym potencjalny czytelnik będzie wiedział, że wypowiada ono prawdę zarówno o indywidualnym życiu danej jednostki, jak i o świecie, do którego ona przynależy ${ }^{33}$. To literacka panorama naszej rzeczywistości. Zwierciadło, w lustrze którego każdy z nas może się uważnie przyjrzeć.

30 Tamże, s. 476.

31 Tamże, s. 176-177.

32 Tamże, s. 177.

33 Tamże. 
Powieści artysty kształtują się - wedle uczonego - wokół „ja”, które na swój sposób nie tylko przytacza, lecz też ożywia przeszłość, albowiem wchodzi ono z nią w twórczą interakcję. Stanowi strukturę, z której zbudowany pozostaje świat $w$ tych utworach. Tworzy wręcz jego ontologiczny wymiar ${ }^{34}$. Nadaje mu więc wiele z wymiaru stricte metafizycznego. Dotyka tego, co związane z pytaniem o istnienie Boga, pozazmysłowe, niedostępne zwykłemu ludzkiemu doświadczeniu, transcendentne, obce, zagadkowe, ahistoryczne, abstrakcyjne, antydialektyczne, statyczne, oniryczne, a także aprioryczne ${ }^{35}$.

Ponadto sposób opowiadania u Myśliwskiego sprawia nieodłączne wrażenie, że zdarzenia, o których jest tutaj mowa, ponownie dzieją się w czasie teraźniejszym, jakby toczyły się przed oczami ich potencjalnych odbiorców, mimo iż - jak się domyślamy - należą one w głównej mierze do dalekiej przeszłości ${ }^{36}$. Biłos zwraca tu uwagę na jeszcze jedną ważną rzecz: „Mimo że w powieściach Myśliwskiego widać wielkie zainteresowanie przeszłością, ale także wolę jej odzyskania czy może raczej ponownego powołania do życia [...], to jednak odżegnują się one znacząco od postawy nostalgicznej”"37. To zresztą jeden z czynników ich antynomicznej budowy ${ }^{38}$. Uniwersum powieści pozostaje bowiem znaczeniowo bardzo zróżnicowane. Każdy z utworów stanowi osobny świat na trajektorii jego pisarstwa. Są one niczym świetnie wyszkolone armie prowadzące ze sobą nieustannie wojnę na słowa i opowiedziane historie. Uczony dodaje również, że:

[...] świat przeszłości [powieści Myśliwskiego - M. S.] odznacza się [...] dynamiką i spójnością szczególnego rodzaju, gdyż spaja ona nie tylko przeszłość w jej naturalnych, by tak rzec, granicach, ale także tę przeszłość z aktualnym stanem ducha „ja”-opowiadacza, jego wrażliwością, wyobraźnią i świadomością. Te zaś stanowią czynniki bezpośrednio wpływające na kształt, jaki przeszłość przybiera w opowieści.

34 Tamże, s. 194

35 Zob. M. Siedlecki, dz. cyt., s. 15-16.

36 P. Biłos, dz. cyt., s. 195.

37 Tamże, s. 197.

38 Tamże. 
[...] Akt opowieści kwestionuje zatem szczelną granicę między tym, co było, a tym, co jest obecnie ${ }^{39}$.

Fabuła utworów Myśliwskiego burzy normalne pojmowanie czasu. To bardziej temporalność wewnętrzna ,ja”-opowiadacza kształtuje cykl zdarzeń w tekstach artysty. Jest główną osią spajającą świat przedstawiony dzieł pisarza. Wydaje się tu wraz z przestrzenią konstruktem iście relatywnym ${ }^{40}$. W opinii Biłosa, celem bohaterów Myśliwskiego staje się swego rodzaju rekonstrukcja za pomocą opowieści, obficie czerpiącej z przeszłości, acz wykraczającej też poza nią, chociażby z tego powodu, że stymuluje ją to wszystko, co zawiera chwila bieżąca ${ }^{41}$. Warto też pamiętać, ,[...] że dla Myśliwskiego świat ujawnić się może tylko w obliczu pojedynczego człowieka, a to oznacza, że to, co było, nie zaistnieje naprawdę dopóty, dopóki nie stanie się przedmiotem opowieści takiej jednostki"42. Ona ją bowiem stale kreuje. Konstytuuje z subtelnych pokładów własnej psyche. Ożywia stanem swego ducha. Gdyby nie „opowiadacz" i ranga, jaką on piastuje w tekstach pisarza, przeszłość nigdy by nie uzyskała tu treści ani kształtu, w które wyposaża ją dana opowieść. Wszystko u Myśliwskiego zdaje się do gruntu przemyślane. Byt oraz ludzkie słowo o nim traktujące wiąże z kolei artysta ściśle ze sobą. To stany nierozerwalne. Utwory prozaika utkane zostały z nieskończenie ruchomego oraz zawsze niedokończonego charakteru rzeczywistości. Nie wiodą one jednak - jak u Marcela Prousta (1871-1922) - ku powieściowemu odnalezieniu przeszłości, acz występuje w nich swego rodzaju wiara w nieograniczoną moc słowa ${ }^{43}$.

\section{Metafizyka}

U Myśliwskiego - na co zwraca uwagę Biłos - opowieść prowadzona ex post transformuje materię przeszłości. Dzięki niej przeszłość doznaje stanów katarktycznych, zostaje poniekąd wypchnięta na poziom swoistego ,„[...] ocalenia. Samej przeszłości jako bytu niezależnego tutaj nie ma, jest za to gest

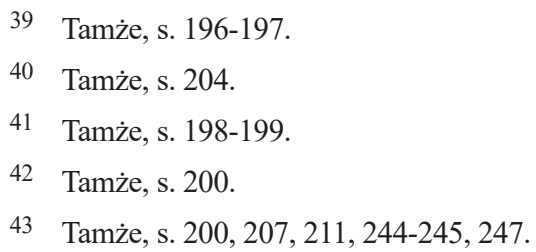


opowiadania, który z pozycji chwili teraźniejszej tę przeszłość przeobraża i właśnie ocala"44. Ukierunkowuje ją w stronę tak zwanej narracji metafizycznej. Wyznaczają ją tutaj następujące elementy: stylizacja biblijna (z jej symboliczno-alegoryczno-metaforycznym językiem); enigmatyczne opisy rzeczywistości determinujące złożony portret natury ludzkiej, w którym naczelną rolę odgrywa prymat wartości „duchowych” nad wszelkimi sądami „racjonalistycznymi”; liczne odwołania do podań ludowych, religii chrześcijańskiej, historii oraz kultury polskiej, jak również do szeroko pojętej „psychologii” i XX-wiecznej „myśli filozoficznej”; obrazowanie kosmogoniczno-mityczne; „plastyczność”, jak też „poetyckość” form słownych oraz baśniowość świata przedstawionego ${ }^{45}$.

Powyższej „narracji” towarzyszą w dziełach Myśliwskiego zazwyczaj monologi wewnętrzne postaci (pełne odniesień do „sytuacji granicznych” człowieka), a także metafizyczne mowy czołowych bohaterów jego utworów - zawarte w rozbudowanej warstwie dialogowej tych literackich tekstów ${ }^{46}$. Utwory Myśliwskiego determinuje jeszcze co najmniej jeden istotny czynnik. Biłos twierdzi bowiem między innymi, że:

Przez opowieści Myśliwskiego prześwituje aksjomat głoszący, że czas nie podlega porządkowi linearnemu i że przeszłości nie da się odłączyć od tego, co po niej następuje. Żeby zrozumieć tę więź, jaka między nimi zachodzi, najlepiej odnieść się do procesu wywoływania zdjęć - podobnie jak negatyw, obraz przeszłości potrzebuje czasu, aby zostać wywołany, a sama przeszłość tai w sobie zapowiedź przyszłości, bo ta, wzywając przeszłość na scenę świadomości, wystawia jej świadectwo istnienia i doprowadza ją do - jakiegoś, a zatem nigdy nieostatecznego - skutku47.

Motyw zdjęcia jako metafory ludzkiego istnienia pozostaje stale obecny w powieściach Myśliwskiego. Stanowi metafizyczną przestrzeń losów bohaterów. Jest kanwą ich codziennych perypetii ze zrządzeniami bezwzględnego

44 Tamże, s. 272.

45 M. Siedlecki, dz. cyt., s. 95-96.

46 Tamże, s. 96.

47 P. Biłos, dz. cyt., s. 291. 
fatum. Badacz twierdzi również, że utwory pisarza rozrastają się i ożywiają w przestrzeni, w której naczelną rolę odgrywa ekspansywne ,ja”. Nawet jeżeli pozostaje ono mniej lub bardziej zajęte sobą, staje się wreszcie bohaterem historii wciąż rozszerzającej się na nowe i częstokroć zadziwiające postaci. Ważną funkcję pełni też u pisarza słowo, które wydaje się w jego tekstach czymś więcej niż ekspresją czy komunikacją. Wyznacza bowiem ontologiczny wymiar świata przedstawionego. To wręcz pierwsza zasada bytu ${ }^{48}$. Znowu więc wracamy do kwestii metafizycznych, nie uwzględnianych przez Biłosa w jego monografii. Nie samo mówienie wydaje się wszak u Myśliwskiego najważniejsze, a to przez jaki pryzmat i w jakim duchu je interpretujemy.

Uczony francuski wychodzi też z założenia, że utwory Myśliwskiego możemy traktować w kategoriach spowiedzi danego bohatera/narratora $\mathrm{z}$ całego swojego życia. Ta słowna ekspiacja adresowana jest tutaj do konkretnego odbiorcy oraz silnie naznaczona oralnością. Cechują ją zazwyczaj wyrafinowany rodzaj monologu. Ponadto u podstaw specyficznej mocy, którą obdarzone jest słowo w powieściach prozaika lokuje się ciągła intensyfikacja oraz akcentowanie napięcia pomiędzy ,ja"-opowiadaczem oderwanym od gromady ludzkiej a aktem komunii z nią ${ }^{49}$. Przez utwory artysty przewija się bowiem ,[...] niewzruszona wiara w moc kreacyjną słowa, w jego zdolność do przemodelowania tożsamości oraz ścieżki życia w los, który nawet jeśli nie stanowi wyniku zawsze celowych wyborów, to nabiera cech indywidualnych" ${ }^{50}$. Myśliwski zawsze wielką wagę przykłada do słów, do ich poprawności i potencjału, jaki się w nich skrywa. Jeden z wywiadów przeprowadzonych z pisarzem nosił nawet tytuł: ...walczę ze stowem jak ze smokiem ${ }^{51}$. One to wiodą jego bohaterów do świata wyobraźni:

Bardzo często u Myśliwskiego fikcja wykracza poza to, co w ramach zmyślonego świata przedstawione jest jako zdarzające się realnie. Podczas gdy światy wymyślone przez pisarza zmierzają do zakorzenienia i powierza się znaczącą rolę czynnikom dążącym do ich oswojenia, podlegają one jednocześnie ciśnie-

48 Tamże, s. 295, 297.

49 Tamże, s. 323, 330, 350.

50 Tamże, s. 359.

51 W. Myśliwski, ...walczę ze stowem jak ze smokiem, rozm. przepr. I. Bodnar, „Przekrój” 1993, nr 47. 
niu sił wyobrażeniowych, odpowiedzialnych za wkradanie się obrazów, których moc mimetyczna jest odwrotnie proporcjonalna do ich realnego dziania się, ich faktyczności, gdyż obrazy te odtwarzają zdarzenia rozgrywające się w sferze wyobraźni. Wyobraźnia to bardzo często broń ludzi bezbronnych i to właśnie z niej najczęściej korzystają postaci wymyślone przez autora ${ }^{52}$.

Świat wyobraźni to kolejna z metafizycznych sfer w pisarstwie Myśliwskiego. Wyróżnia ona wszystkie dzieła pisarza. Jest odzwierciedleniem oryginalnych i fantasmagorycznych światów wewnętrznych głównych bohaterów. Konstytuuje przesłania tekstów. Stanowi ich kościec znaczeniowy. Pozostaje fundamentem, na którym zbudował twórca fabuły dzieł.

Biłos wskazuje na zdolność człowieka Myśliwskiego do przemieniania za pomocą wyobraźni bolesnej po wielokroć codzienności. Żywym emblematem owego procesu pozostaje główny bohater Kamienia na kamieniu - Szymon Pietruszka. Podobnie sytuacja wygląda w Traktacie o tuskaniu fasoli oraz w Ostatnim rozdaniu. Realne podłoże, z którego wyrastają zachowania czołowych postaci powieści autora Nagiego sadu wzmacnia niejednokrotnie poczucie niepewności, co do rzeczywistego podłoża poszczególnych zdarzeń, w których biorą oni czynny udział. Badacz zwraca też uwagę na cechy sztandarowych postaci utworów prozaika, w tym śledzi rolę, jaką odgrywają w nich narratorzy, nazywając ich nawet mianem wspomnianych ,opowiadaczy", którzy okazują się u pisarza silnie zindywidualizowani. Opowieść ramowa, będąca domeną ,ja"-opowiadacza, posiada tutaj charakter głęboko osobisty. Opowiadane przez niego zdarzenia nasycają się oraz zabarwiają jego uczuciowością, wnętrzem, jak też specyficznym nastawieniem do świata ${ }^{53}$.

U Myśliwskiego sama ,[...] aktywność werbalna, w wymiarze zarówno czysto ludzkim, jak i kosmologicznym, wyprzedza, podtrzymuje, napędza ontologię"54. Ponownie wracamy więc do kwestii metafizyki. Do jej czołowych zagadnień. Ta klasyczna dziedzina wiedzy - o istotnych własnościach i ostatecznych przyczynach idei ,bytu” - została ukonstytuowana przez Arystotelesa w jego dziele Metafizyka (IV w. p.n.e.). Stagiryta określił ją nawet

52 P. Biłos, dz. cyt., s. 360.

53 Tamże, s. 376, 378, 390.

54 Tamże, s. 396. 
mianem „filozofii pierwszej”, bowiem odwołują się do niej wszystkie nauki szczegółowe oraz tak zwana „wiedza boska” - czyli „teologia” - ze względu na poznanie ostatecznych przyczyn każdej rzeczy. Metafizyka Arystotelesa mająca za przedmiot „byt jako byt” - stała się więc bodźcem do rozwoju takich systemów myślowych, jak nauka: „o Bogu”; „o przyrodzie” i „o duszy”. Dzięki niej ukształtowane zostały zatem następujące pojęcia: „forma”, „materia”, „energia”, „potencja”, a także „istota rzeczy”. To również „dziedzina wiedzy o pryncypiach" - pierwszych zasadach strukturalnych - bytu jako jednostkowej substancji i jej zewnętrznych przyczynach sprawczych, jak też celowych ${ }^{55}$.

Metafizyka stanowi klucz interpretacyjny do dzieł Myśliwskiego. Ontologiczne ujmowanie świata znamionuje większość dzieł prozatorskich tego artysty. Powieści Myśliwskiego stoją w niemal całkowitej opozycji do utworów nacechowanych społecznie czy politycznie. Twórczość Myśliwskiego obfituje w opisy metafizycznych relacji człowieka z otaczającym go uniwersum. Świat wewnętrzny bohaterów powieści również jest determinowany przez to, co transcendentne, pozazmysłowe i nieokreślone. Myśli i czyny tych postaci można więc tutaj interpretować jako próbę zmierzenia się istoty ludzkiej $\mathrm{z}$ odwieczną tajemnicą istnienia ${ }^{56}$.

\section{W samym środku tożsamości}

Interpretator wychodzi w monografii z założenia, że stosunek do tego, co inne, umiejscowiony w samym środku tożsamości, to „[...] jedna z naczelnych zasad powieściowej logistyki, jaką ujawniły nasze interpretacyjne wysiłki”"57. Trudno jednak z owej sugestii badacza, co staraliśmy się tutaj udowodnić, wyprowadzać tezę o zbieżności powieściowych światów Myśliwskiego. Granice między nimi wydają się, na przekór twierdzeniom uczonego, również raczej nieprzekraczalne, a na pewno nie w sposób, jaki on sugeruje. Nie rezonują one ze sobą w sposób twórczy. Owszem stanowią o kreacyjnym potencjale pisarza, acz nie wskazują, jakoby artysta tworzył ze swoich tekstów literackich jedno wielkie dzieło. Obce naszym poglądom wydaje się także postulowane

55 M. Siedlecki, dz. cyt., s. 50. Por. Arystoteles, Metafizyka, [w:] tegoż, Dzieła wszystkie, t. II, red. i przeł. K. Leśniak, Warszawa 1990, 981b, 983a, s. 618, 620.

56 M. Siedlecki, dz. cyt., s. 15, 18.

57 P. Biłos, dz. cyt., s. 497. 
przez Biłosa zjawisko ciągłych nawrotów, powstawania wariantów oraz ech określonych schematów fabularnych, jak też motywów. W niczym nie pomoże tutaj sugerowana przez badacza wielokrotna/spiralna lektura utworów artysty. Choćby nie wiem, jak była ona przez potencjalnego czytelnika wznawiana niczego definitywnie nam nie udowodni. Nie jest też tak, że z powieści na powieść pewne elementy tekstu powtarzają się. Nie tworzą wcale ech przekształcających stałe czy wręcz archetypiczne motywy. Główne punkty struktury cyklu powieściowego pisarza nie składają się na jakiś jego szczególny rytm ${ }^{58}$.

W książce Biłosa można też zauważyć, co najmniej jeden ważny błąd czy niedopatrzenie. Wspomniana przez badacza na stronie trzysta dziewięćdziesiątej siódmej scena ukrywania się dwóch bohaterów Kamienia na kamieniu w cmentarnym grobie przed Niemcami nie ocaliła im obu, jak to podaje uczony, życia, gdyż jeden z nich umarł:

Pochowałem go na tym samym cmentarzu, w gołej ziemi, bez trumny, bez pogrzebu. Uklepałem mu kopczyk, zrobiłem krzyż, przeniosłem wieniec z tego grobu Siewierskich, gdzie siedzieliśmy, bo skoro dranie, to nie muszą mieć wienca, i zagrałem mu na organkach, bo zawsze nosiłem organki przy sobie. Oj, ty głupi „Trzmielu”. Dłubałeś, to trza było dłubać59.

W monografii Biłosa odnajdziemy też trochę przeinaczeń interpunkcyjnych i leksykalnych oraz nieco niedopatrzeń w zestawieniach alfabetycznych w Indeksie postaci. Mimo tych drobnych uchybień i odważnych sądów badacza, przewartościowujących obecne spojrzenie na dzieła Myśliwskiego, jego książka stanowi istotną interpretację tekstów pisarza. Podejmuje ważne wątki badawcze, a w wielu z nich pozostaje prekursorska na gruncie analizy utworów autora Pałacu. Trudno wobec niej przejść obojętnie, tym bardziej, że samych monografii na temat dorobku Myśliwskiego nie jest znowu, o czym była już na wstępie mowa, aż tak dużo. Warto więc czytać Biłosa, by z nieco odmiennej niż dotychczas perspektywy spojrzeć na całokształt dokonań literackich pisarza. To nader intrygująca i pełna inspiracji lektura. Ważny głos młodego pokolenia badaczy. Polecam tę książkę wszystkim.

59 Zob. W. Myśliwski, Kamień na kamieniu, Kraków 2008, s. 32. 


\section{Bibliografia}

Arystoteles, Metafizyka, [w:] Arystoteles, Dzieła wszystkie, t. II, red. i przeł. K. Leśniak, Warszawa 1990.

Bereza H., Związki naturalne. Szkice literackie, Warszawa 1972.

Biłos P., Powieściowe światy Wiesława Myśliwskiego, Kraków 2017.

Dziekanowski Cz., Proza „życia w śmierci”. Psychoanaliza twórczości powieściowej Wiesława Myśliwskiego, Białystok 1990.

Dziekanowski Cz., W imię ojca i syna, Warszawa 1993.

Dziekanowski Cz., Życie jaśnie pana, Warszawa 1994.

Dziekanowski Cz., Życie w śmierci, Warszawa 1995.

Kulesza D., Epopeja. Myśliwski, Herbert, Mrożek, Białystok 2016.

Myśliwski W., Kamień na kamieniu, Kraków 2008.

Myśliwski W., Nagi sad, Warszawa 1997.

Myśliwski W., Ostatnie rozdanie, Kraków 2013.

Myśliwski W., Pałac, Szczecin 1988.

Myśliwski W., Traktat o łuskaniu fasoli, Kraków 2007.

Myśliwski W., Ucho igielne, Kraków 2018.

Myśliwski W., Widnokrąg, Warszawa 2000.

Siedlecki M., Myśliwski metafizyczny. Rozważania o "Widnokręgu" i "Traktacie o łuskaniu fasoli", Białystok 2015.

Ziątek Z., Wiek dokumentu. Inspiracje dokumentarne w polskiej prozie wspótczesnej, Warszawa 1999. 